\title{
Calcium metabolism in lactating ewes
}

\author{
By G. D. BRAITHWAITE, R. F. GLASCOCK AND SH. RIAZUDDIN \\ National Institute for Research in Dairying, Shinfield, Reading \\ (Received 30 January 1969-Accepted 28 May 1969)
}

\begin{abstract}
I. A combination of balance and isotope techniques has been used to study calcium metabolism at different stages of lactation in six sheep and the results have been compared with those obtained from four of the sheep I month after the end of lactation.

2. At first the animals were in negative $\mathrm{Ca}$ balance but, as milk yields decreased, so the animals moved progressively into positive balance.

3. Ca absorption from the gut was significantly increased throughout the whole of lactation but not sufficiently to meet the initial high demands for $\mathrm{Ca}$.

4. Most of the extra $\mathrm{Ca}$ was supplied by bone resorption which was high in early lactation and decreased to a very low value at the end.

5. The rate of bone accretion remained constant throughout the period and was I'5 times as high as in the non-lactating animals.

6. In the later stages, a combination of factors, but in particular a low rate of resorption of bone, enabled the animals to replenish some of the Ca lost from the skeleton in early lactation. 7. A month after the end of lactation replenishment of skeletal stores of $\mathrm{Ca}$ was still continuing as shown by the excess of bone accretion over bone resorption.
\end{abstract}

At the onset of lactation, requirements for $\mathrm{Ca}$ are substantially increased (Symonds, Manston, Payne \& Sansom, I966) and in the early stages of lactation animals are usually found to be in negative Ca balance (Keller, 1961). This indicates that the increased demands for $\mathrm{Ca}$ resulting from milk production are not met by dietary $\mathrm{Ca}$ alone and it is generally assumed that the extra $\mathrm{Ca}$ is provided by mobilization of mineral stores. Loss of $\mathrm{Ca}$ from the skeleton during lactation has been observed (Duckworth \& Hill, 1954) but no attempt has been made to measure rates of bone accretion and resorption.

The purpose of the present work was to obtain more information on the source of milk $\mathrm{Ca}$ at different stages of lactation and on the effect of lactation on skeletal metabolism.

The technique used is that of Aubert \& Milhaud (1960), which allows measurement, in the living animal, of bone accretion and resorption rates.

\section{EXPERIMENTAL}

Animals, housing and diet. Six 3-year-old half-bred ewes (Border Leicester $\times$ Cheviot) in their second lactation were used for these investigations. Immediately after lambing they were placed in metabolism cages designed for the separate collection of urine and faeces. The ewes were machine milked twice a day (Morag, Gibb \& Fox, I967) until the daily yield of milk fell to $500 \mathrm{ml}$ (usually about to weeks post partum) and then once a day.

Experiments, each lasting a week, were performed on ewes at four different stages of lactation, ewe no. 492 from $\mathrm{r}_{4}$ days, nos. 490 and 493 from $3 \mathrm{I}$ days, nos. $49 \mathrm{I}$ and 
494 from 6r days and nos. 490 and 495 from 88 days. The experiments were repeated on four of the ewes I month after the end of lactation. The animals were fed a diet of hay and concentrates, the composition and $\mathrm{Ca}$ content of which are given in Table I. Concentrates were fed during milking and hay immediately after morning milking. Uneaten food was collected daily and the total amount consumed was determined. The animals had free access to distilled water.

Table I. Composition and calcium content of the diet given daily

\begin{tabular}{|c|c|c|c|}
\hline Ingredient & $\underset{(\mathrm{g})}{\text { Amount }}$ & $\begin{array}{c}\text { Ca content } \\
(\mathrm{mg} / \mathrm{g})\end{array}$ & $\begin{array}{c}\text { Total Ca } \\
\text { (mg) }\end{array}$ \\
\hline Hay & I 100 & $6 \cdot 20$ & $6820 \cdot 0$ \\
\hline Barley & 320 & 0.52 & $\mathrm{x} 66 \cdot 4$ \\
\hline Flaked maize & 160 & 0.02 & $3 \cdot 2$ \\
\hline Bran & 80 & $0.7 \mathrm{I}$ & $56 \cdot 8$ \\
\hline Linseed oil cake & 40 & $3 \cdot$ I I & $124^{\circ} 4$ \\
\hline Mineral mixture* & 20 & $196 \cdot 84$ & $3936 \cdot 8$ \\
\hline Vitamin mixture & $2 \cdot 8$ & 3.79 & $10 \cdot 6$ \\
\hline
\end{tabular}

* 'Super Mindif', Boots Pure Drug Co., Nottingham.

$\dagger$ 'Drivite', Boots Pure Drug Co., Nottingham. To supply 12500 i.u. vitamin A and 3roo i.u. cholecalciferol.

Experimental procedure. Calcium- 45 as ${ }^{45} \mathrm{CaCl}_{2}$ in aqueous solution was bought from the Radiochemical Centre, Amersham.

A known activity (about $200 \mu \mathrm{c}$ ) was injected into the jugular vein immediately after the morning milking and blood samples were then withdrawn from a jugular cannula every $0.5 \mathrm{~min}$ from I to $5 \mathrm{~min}$, every I min from 5 to $10 \mathrm{~min}$, every $2 \mathrm{~min}$ from Io to $20 \mathrm{~min}$, every $\mathrm{I} 5 \mathrm{~min}$ from 30 to $\mathrm{I} 5 \mathrm{O}$ min, every hour from 4 to $\mathrm{II} h$, then every $3 \mathrm{~h}$ except at night, to 7 days. During this period $\mathrm{Ca}$ balance measurements were made.

Urine was collected daily in a vessel containing $100 \mathrm{ml} 10 \%$ acetic acid to prevent putrefaction and the total volume was measured. Faeces were also collected daily from the time at which radioactivity first appeared in them, which was usually about $5 \mathrm{~h}$ after dosing. Milk volumes were measured at each milking and samples preserved for analysis.

Preparation of the sample for analysis. Blood samples were allowed to clot at room temperature; they were then centrifuged at $2500 \mathrm{~g}$ and the serum was separated.

Faeces were dried at $80^{\circ}$, weighed, ground to a fine powder and thoroughly mixed. Samples (ro g) of food and dry powdered faeces were then ashed at $600^{\circ}$ and the ash was dissolved in $100 \mathrm{ml} 2 \mathrm{~N}-\mathrm{HCl}$.

Milk samples were wet-ashed by the method of Smith \& McAllan (r966). Urine samples were analysed without any further treatment.

Determination of $\mathrm{Ca}$. Total $\mathrm{Ca}$ in all samples was measured by atomic absorption spectrophotometry, in food, urine, faeces and milk by the method of Willis (I96I) and in serum by the method of Willis $(1960 a, b)$.

Measurement of radioactivity. Radioactivity was measured in a Tri-Carb Liquid 
Scintillation Spectrometer (Packard model 3314) and corrections for quenching and decay were made by the internal standard technique.

Samples of serum ( $\mathrm{I} \mathrm{ml}$, acidified with 3 drops of $2 \mathrm{~N}-\mathrm{HCl})$, milk $(0.5 \mathrm{ml}+0.5 \mathrm{ml}$ $2 \mathrm{~N}-\mathrm{HCl}$ ) and the solution of ashed faeces in $\mathrm{HCl}(\mathrm{I} \mathrm{ml})$ were counted in $10 \mathrm{ml}$ of a scintillator solution containing $400 \mathrm{ml}$ of anisole, $600 \mathrm{ml}$ of methoxyethanol, $100 \mathrm{~g}$ of naphthalene, $7.0 \mathrm{~g}$ of 2,5-diphenyloxazole and $0.3 \mathrm{~g}$ of I,4-bis-(5-phenyloxazole-2-yl) benzene. Samples of urine ( $1 \mathrm{ml}$ acidified with 3 drops of $2 \mathrm{~N}-\mathrm{HCl}$ ) were counted in ro $\mathrm{ml}$ of a scintillator solution containing $4 \mathrm{~g}$ of 2,5 -diphenyloxazole and $0.3 \mathrm{~g}$ of I,4-bis-(5-phenyloxazole-2-yl)benzene dissolved in a mixture of $500 \mathrm{ml}$ of Triton X-100 (The Rohm and Haas Company, Philadelphia, USA) and I 1 . of toluene. Single samples of serum were assayed but other solutions were assayed in replicate (up to four samples).

Kinetic analysis. The various methods of kinetic analysis have been reviewed by Aubert, Bronner \& Richelle (1963). The general method of Aubert \& Milhaud (I960) as applied to man was chosen for this work in preference to any of the simplified methods, which although useful for comparative studies considerably overestimate the size of the exchangeable $\mathrm{Ca}$ pool $P$ and the rate of accretion of $\mathrm{Ca}$ into bone $V_{0+}$.

The present method involves a combination of a balance and radioactive technique. Specific radioactivity of the serum $\mathrm{Ca}$ was plotted against time on semi-logarithmic co-ordinates and the equation of the complete curve extending over a period of 7 days was calculated by the method of Feurzeig \& Tyler (1950). The equation was solved by the method of Parsons ( 1968 ), and values for the various processes of Ca metabolism were then calculated by an extension, required for lactating animals, of the method of Aubert \& Milhaud (1960). This depends essentially on the equation

$$
V_{T}=V_{u}+V_{f}+V_{l}+V_{0+}
$$

where $V_{T}$ is the rate of irreversible flow of Ca from the pool $P$ (see below), $V_{u}$ the rate of excretion of $\mathrm{Ca}$ in urine, $V_{f}$ the rate of excretion into the intestine (faecal endogenous $\mathrm{Ca}$ ), $V_{l}$ the rate of secretion of $\mathrm{Ca}$ into milk and $V_{0+}$ the rate of accretion of $\mathrm{Ca}$ into bone.

\section{RESULTS}

Calcium pools. The equations of the specific radioactivity time curves were found to consist of six exponential terms. In similar experiments on man, Aubert $\&$ Milhaud (I960) found that the curve could be represented by an equation with five terms from which they deduced the existence of five $\mathrm{Ca}$ compartments. One was serum $\mathrm{Ca}$, with which three others were in rapid equilibrium and together formed the pool $P$, while the fifth exchanged much more slowly with serum $\mathrm{Ca}$ and was taken to be the slowly exchangeable $\mathrm{Ca}$ of bone $(E)$. In the present work, the resolution of the curve on semi-logarithmic co-ordinates into its component straight lines showed that in the sheep the extra exponential term was due to a compartment which equilibrated with serum Ca within the first few minutes. This would not be detected in the experiments of Aubert \& Milhaud on man as their first blood sample was taken 5 min after the injection of radioactive $\mathrm{Ca}$, whereas in the present work ten samples were taken during 
this period (see p. 828). In accordance with the theory of Aubert \& Milhaud (1960) we therefore infer the existence in the sheep of five compartments of $\mathrm{Ca}$ in addition to serum $\mathrm{Ca}$, of which all but the one exchanging most slowly with it are subcompartments of pool $P$. This slowly exchanging compartment, represented by the monoexponential decay of the specific radioactivity time curve between $72 \mathrm{~h}$ and the end of the experiment ( $\mathrm{I} 68 \mathrm{~h}$ ), is again taken to be in bone $(E)$.

\section{Table 2. Calcium metabolism in the ewe at different stages of lactation}

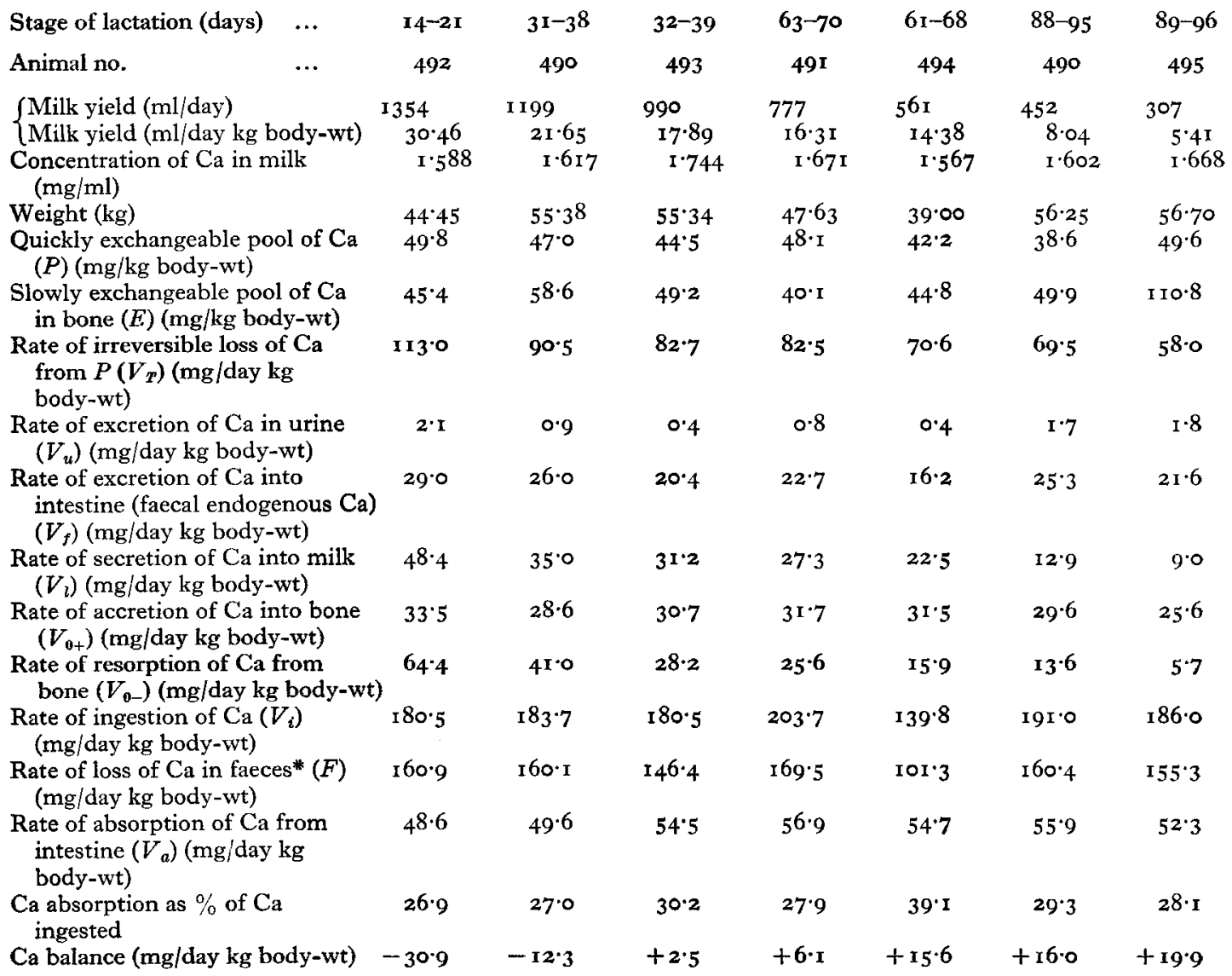

* Sum of faecal endogenous Ca and unabsorbed Ca lost per day.

Young, Luick \& Lofgreen (1966), also working on sheep, consider however that the monoexponential decay of specific radioactivity of $\mathrm{Ca}$ observed between 60 and I $80 \mathrm{~h}$ represented penetration of $\mathrm{Ca}$ into a single pool which they designate as $E$. This pool thus corresponds to pools $P+E$ in the present work.

Lactation. Table 2 shows the values of various transfer and exchange rates and pool sizes of $\mathrm{Ca}$ in ewes listed in order of decreasing milk yield.

In early lactation, when both the milk yields and the resulting demands for $\mathrm{Ca}$ in the milk were high, the animals were in negative $\mathrm{Ca}$ balance. As lactation progressed 
and the milk yield decreased, the animals moved into positive balance. Throughout the whole period of lactation only the rate of bone resorption altered markedly. The value was very high in early lactation when requirements for $\mathrm{Ca}$ were high and it diminished to a very low value as milk yield diminished towards the end of lactation.

To ensure that absorption of $\mathrm{Ca}$ was not being limited by the availability of $\mathrm{Ca}$ in the diet, the intake of one ewe (no. 494) was reduced to about $70 \%$ of that of the other animals by reducing the ration of both hay and concentrates. The amount of Ca absorbed per day was found to be the same as in sheep on full rations $(54.7 \mathrm{mg} / \mathrm{day}$ per $\mathrm{kg}$ body-weight), so that the proportion of the total dietary $\mathrm{Ca}$ absorbed was correspondingly higher (39. I \% instead of $27 \%-30 \%)$.

\section{Table 3. A comparison of calcium metabolism in lactating and non-lactating ewes}

(Ranges or mean values with their standard error and result of tests of significance (as determined by the $t$ test))

\begin{tabular}{|c|c|c|c|}
\hline \multicolumn{3}{|c|}{ 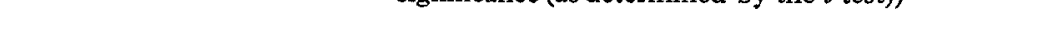 } & \multirow{2}{*}{$\begin{array}{c}\text { Significance of } \\
\text { difference } \\
\text { between means }\end{array}$} \\
\hline & $\begin{array}{c}\text { Lactating } \\
\text { sheep }\end{array}$ & $\begin{array}{l}\text { Non-lactating } \\
\text { sheep }\end{array}$ & \\
\hline $\begin{array}{l}\text { Quickly exchangeable pool of } \mathrm{Ca}(P) \\
(\mathrm{mg} / \mathrm{kg} \text { body-wt) }\end{array}$ & $45 \cdot 7 \pm x \cdot 6$ & $38 \cdot I \pm 2 \cdot 0$ & $*$ \\
\hline $\begin{array}{l}\text { Slowly exchangeable pool of } \mathrm{Ca} \text { in bone }(E) \\
(\mathrm{mg} / \mathrm{kg} \text { body-wt) }\end{array}$ & $48 \cdot 0 \pm 2 \cdot 6$ & $39^{-} 5 \pm 3 \cdot 1$ & * \\
\hline $\begin{array}{l}\text { Rate of irreversible loss of Ca from } P\left(V_{T}\right) \\
(\mathrm{mg} / \text { day kg body-wt) }\end{array}$ & I 13.0 to $58 \cdot 0+$ & $43 \cdot 5 \pm 4 \cdot 0$ & \\
\hline $\begin{array}{l}\text { Rate of excretion of Ca in urine }\left(V_{u}\right) \\
(\mathrm{mg} / \text { day } \mathrm{kg} \text { body-wt) }\end{array}$ & $I \cdot 2 \pm 0 \cdot 3$ & $4 \cdot I \pm I \cdot 3$ & * \\
\hline $\begin{array}{l}\text { Rate of excretion of Ca into intestine (faecal } \\
\text { endogenous } \mathrm{Ca})\left(V_{f}\right)(\mathrm{mg} / \text { day } \mathrm{kg} \text { body-wt) }\end{array}$ & $24 \cdot 2 \pm r \cdot 3$ & $19.1 \pm 0.9$ & * \\
\hline $\begin{array}{l}\text { Rate of secretion of Ca into milk }\left(V_{l}\right) \\
\text { (mg/day kg body-wt) }\end{array}$ & $48 \cdot 4$ to $9 \cdot 0$ of & & \\
\hline $\begin{array}{l}\text { Rate of accretion of } \mathrm{Ca} \text { into bone }\left(V_{0+}\right) \\
(\mathrm{mg} / \text { day } \mathrm{kg} \text { body-wt) }\end{array}$ & $30 \cdot 2 \pm 1 \cdot 0$ & $20 \cdot 3 \pm 2 \cdot 6$ & ** \\
\hline $\begin{array}{l}\text { Rate of resorption of Ca from bone }\left(V_{0-}\right) \\
(\mathrm{mg} / \text { day } \mathrm{kg} \text { body-wt) }\end{array}$ & 64.4 to $5.7 \dagger$ & $\mathrm{I} 4 \cdot \mathrm{I} \pm \mathbf{3} \cdot \mathrm{O}$ & \\
\hline $\begin{array}{l}\text { Rate of ingestion of } \mathrm{Ca}\left(V_{i}\right)(\mathrm{mg} / \text { day } \mathrm{kg} \\
\text { body-wt) }\end{array}$ & $187 \cdot 6 \pm 3 \cdot 6$ & $165 \cdot 1 \pm 11 \cdot 3$ & NS \\
\hline $\begin{array}{l}\text { Rate of loss of } \mathrm{Ca} \text { in faeces }(F)(\mathrm{mg} / \mathrm{day} \mathrm{kg} \\
\text { body-wt) }\end{array}$ & ${ }^{\prime} 58 \cdot 8 \pm 3 \cdot 1$ & I $54 \cdot 8 \pm$ I I 4 & NS \\
\hline $\begin{array}{l}\text { Rate of absorption of Ca from intestine }\left(V_{a}\right) \\
(\mathrm{mg} / \text { day } \mathrm{kg} \text { body-wt) }\end{array}$ & $53^{\cdot} 2 \pm I \cdot 2$ & $29 \cdot 3 \pm x \cdot 7$ & **** \\
\hline $\begin{array}{l}\mathrm{Ca} \text { balance (mg/day kg body-wt) } \\
\mathrm{Ca} \text { absorption as \% of } \mathrm{Ca} \text { ingested }\end{array}$ & $\begin{array}{c}-30.9 \text { to }+19.9 \dagger \\
28.2 \pm 0.5\end{array}$ & $\begin{array}{r}+6 \cdot 2 \pm I \cdot 3 \\
18 \cdot 0 \pm \mathrm{I} \cdot 5\end{array}$ & **** \\
\hline
\end{tabular}

Values for non-lactating sheep are the mean of four results and for lactating sheep the mean of seven results, with the following exceptions: rates of ingestion of $\mathrm{Ca}$, loss of $\mathrm{Ca}$ into faeces (both total and faecal endogenous) and percentage $\mathrm{Ca}$ absorption for the lactating sheep exclude sheep no. 494 (Table $\mathrm{r}$ ), which was fed a reduced ration (see above). The mean value of the slowly exchangeable pool of $\mathrm{Ca}$ in bone $(E)$ for lactating sheep excludes one exceptionally high result (no. 495, Table I).

* $0.05>P>0.01$; ** $0.01>P>0.001$; *** $0.001>P$.

$\uparrow$ Range of values.

Table 3 shows a comparison of the mean results obtained for the lactating animals with those of four of the ewes I month after the end of lactation. The rates of absorption of dietary $\mathrm{Ca}$, of accretion into bone and of faecal endogenous excretion were significantly higher during lactation, whereas the rate of urinary excretion was lower. 


\section{DISCUSSION}

In order to meet the demands for extra $\mathrm{Ca}$ during lactation, the animal might decrease the rate of accretion into bone and excretion in urine and faeces or increase absorption from the gut and resorption of bone. The present results show that during lactation the rate of accretion into bone was $\mathrm{I}^{-5} 5$ times as high as in the same animals after the end of lactation ( $\mathrm{Table}_{3}$ ) and that there was no evidence of variation in the rate of accretion in response to the stage of lactation (Table 2). Furthermore, faecal endogenous Ca was slightly increased, not decreased, during lactation (Table 3 ) and although urinary $\mathrm{Ca}$ was slightly lower, the levels were too low to affect appreciably the Ca economy of the animals.

Although the rate of absorption of $\mathrm{Ca}$ from the gut did not alter appreciably during lactation (Table 2) it was at a considerably higher level than after the end of lactation $\left(53.2 \mathrm{mg} /\right.$ day per $\mathrm{kg}$ as against $29^{\prime} 3 \mathrm{mg} / \mathrm{day}$ per $\mathrm{kg}$ : Table 3 ). Symonds et al. (1966) also observed an increased absorption in lactating cows but concluded that the increase was not sufficient to supply the needs of lactation. The ewe fed on reduced rations (no. 494, Table 2) absorbed the same amount of $\mathrm{Ca}$ from the diet as the other animals, with a resulting increase in absorption from about $28 \%$ to $39 \%$ suggesting that absorption was not limited by the availability of the dietary $\mathrm{Ca}$. The possibility exists of course that this result obtained from a single experiment is atypical and due only to animal variation but, on the other hand, other workers have also observed similar effects (Bronner, 1964). As the ewes were in negative balance in early lactation in spite of a plentiful supply of $\mathrm{Ca}$ in the diet, it would thus appear that the capacity of the gut to absorb $\mathrm{Ca}$ is limited. In support of this conclusion there is now considerable evidence that an active transport mechanism mediated by vitamin $D$ plays an important part in the absorption of $\mathrm{Ca}$ from the intestinal tract (Schachter \& Rosen, 1959; Schachter, Dowdle \& Schenker, I960; Harrison \& Harrison, 1966; Wasserman \& Taylor, 1966; Kallfelz, Taylor \& Wasserman, 1967) and that an upper limit exists to the amount of $\mathrm{Ca}$ that can be transported (Cramer \& Dueck, I962).

The pathway of Ca metabolism which varied most throughout the period of lactation was the rate of bone resorption. Its value was roughly proportional to milk yield and it is to be noted that it continued to decrease even after the animals had moved into positive balance (ewe no. 493, Table 2). Towards the end of lactation, when the milk yield was low (ewe no. 495), the rate of bone resorption was only about half the mean value for non-lactating females (Table 3) or for mature castrated males (unpublished results). The increased rates of faecal endogenous excretion and of accretion of $\mathrm{Ca}$ into bone throughout the period of lactation both increased the demand for $\mathrm{Ca}$. Later in lactation, when bone resorption had diminished to a very low level, the continuing higher rate of absorption from the gut and of accretion of $\mathrm{Ca}$ into bone enabled the animal to make good earlier losses from the skeleton. A month after the end of lactation replenishment of skeletal stores was still continuing, as shown by the excess of bone accretion over bone resorption, which was also reflected in a positive $\mathrm{Ca}$ balance (Table 3).

The increased size of pool $E$ in bone during lactation may be connected with 
mobilization of $\mathrm{Ca}$, but the increased size of pool $P$, which is mainly in the soft tissues (Aubert \& Milhaud, r960) and which increased to about the same extent as $E$, is, at the present time, inexplicable, as is also the increased rate of faecal endogenous excretion.

Young et al. (1966) found an exchangeable Ca pool in wether lambs of approximately $20 \mathrm{~g}$ compared with a total exchangeable Ca pool (i.e. pools $P+E$ ) of approximately $5 \mathrm{~g}$ in the present work. They, however, used a simple method of kinetic analysis which ignores the large losses of radioactivity from the system in the early part of the experiment $(0-60 \mathrm{~h})$ and grossly overestimates the values of $P$ (Aubert $\&$ Milhaud, I96o; Aubert et al. 1963).

The present results appear to have a bearing on the $\mathrm{Ca}$ requirements of lactating ewes (and, by inference, also on those of lactating cows) as estimated by the authors of Nutrient Requirements of Farm Livestock (Agricultural Research Council, 1965). According to this publication (p. 32) a $50 \mathrm{~kg}$ Lowland ewe requires $280 \mathrm{mg} \mathrm{Ca} / \mathrm{kg}$ in the Ist week of lactation, decreasing to $156 \mathrm{mg} / \mathrm{kg}$ in the $4^{\text {th }}$ week. This work shows that in spite of a plentiful supply of $\mathrm{Ca}$ in the diet animals were unable to absorb more than $28 \%$ of this $\mathrm{Ca}$ and were obliged to draw on the skeleton to meet the high demands of early lactation. Unless this low level of absorption was due to low availability of dietary Ca (which seems unlikely in view of the result for sheep 494), this indicates that the capacity of the gut to absorb Ca was limited to this level. If this is so, supplementation of the diet with $\mathrm{Ca}$ to these levels would be of little avail owing to the low and constant rate of absorption of the element from the intestine.

We thank Mr J. Connell, BSc, for obtaining the sheep, Messrs G. Lovering and J. Rattenbury for technical assistance and Messrs R. Ellis and A. Wilim for looking after the animals. Our thanks are also due to the Computer Unit of Reading University for computation of the results. One of us (Sh. R., a visiting worker from the Pakistan Atomic Energy Commission, Lahore) is the holder of a Colombo Plan Fellowship.

\section{REFERENCES}

Agricultural Research Council (1965). The Nutrient Requirements of Farm Livestock. No. 2. Ruminants. London: H.M. Stationery Office.

Aubert, J.-P., Bronner, F. \& Richelle, L. J. (1963). F. clin. Invest. 42, 885.

Aubert, J.-P. \& Milhaud, G. (1960). Biochim. biophys. Acta 39, 122.

Bronner, F. (1964). In Mineral Metabolism Vol. 2, Part A, Ch. 2o. [C. L. Comar and F. Bronner, editors.] New York and London: Academic Press Inc.

Cramer, C. F. \& Dueck, J. (1962). Am. F. Physiol. 202, 161.

Duckworth, J. \& Hill, R. (1954). F. Physiol., Lond., 123, 69P.

Feurzeig, W. \& Tyler, S. A. (I950). Q. Rep. Argonne natn. Lab., ANL-440I, I4 (quoted by Robertson, I957).

Harrison, H. E. \& Harrison, H. C. (1966). Proc. Soc. exp. Biol. Med. 121, 312.

Kallfelz, F. A., Taylor, A. N. \& Wasserman, R. H. (1967). Proc. Soc. exp. Biol. Med. 125, 54.

Keller, A. (1961). Roczn. Naukroln. Ser, B 78, 231.

Morag, M., Gibb, J. A. C. \& Fox, S. (1967). F. Dairy Res. 34, 215.

Parsons, D. H. (1968). Mathl Biosci. 2, 19ז.

Robertson, J. S. (1957). Physiol. Rev. 37, 133 .

Schachter, D., Dowdle, E. B. \& Schenker, H. (1960). Am. Y. Physiol. 198, 263.

Schachter, D. \& Rosen, S. M. (1959). Am. F. Physiol. 196, 357. 
834 G. D. Braithwaite, R. F. Glascock and Sh. Riazuddin

Smith, R. H. \& McAllan, A. B. (I966). Br. F. Nutr. 20, 703.

Symonds, H. W., Manston, R., Payne, J. M. \& Sansom, B. F. (1966). Br. vet. F. 122, I96.

Wasserman, R. H. \& Taylor, A. N. (1966). Science, N.Y. 152, 791.

Willis, J. B. (1 960a). Spectrochim. Acta 16, 259.

Willis, J. B. (1960b). Spectrochim. Acta 16, 273.

Willis, J. B. (I96I). Analyt. Chem. 33, 556.

Young, V. R., Luick, J. R. \& Lofgreen, G. P. (1966). Br. F. Nutr, 20, 727. 